\title{
Preliminary Study of Cave Sample Storage Conditions on Fungal Community Diversity
}

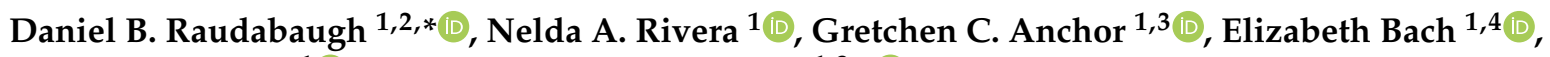 \\ Andrew N. Miller ${ }^{1}(\mathbb{D})$ and Nohra E. Mateus-Pinilla $1,3, *$ (D) \\ 1 Illinois Natural History Survey, University of Illinois, Champaign, IL 61820, USA; river@illinois.edu (N.A.R.); \\ anchor2@illinois.edu (G.C.A.); elizabeth.bach@tnc.org (E.B.); amiller7@illinois.edu (A.N.M.) \\ 2 Department of Plant Biology, University of Illinois, Urbana, IL 61801, USA \\ 3 Department of Natural Resources and Environmental Sciences, University of Illinois, \\ Champaign, IL 61820, USA \\ 4 Nature Conservancy, Nachusa Grasslands, Franklin Grove, IL 61031, USA \\ * Correspondence: raudaba2@illinois.edu (D.B.R.); nohram@illinois.edu (N.E.M.-P.)
}

Citation: Raudabaugh, D.B.; Rivera, N.A.; Anchor, G.C.; Bach, E.; Miller, A.N.; Mateus-Pinilla, N.E. Preliminary Study of Cave Sample Storage Conditions on Fungal Community Diversity. Diversity 2021, 13, 188. https://doi.org/10.3390/ d13050188

Academic Editor: Michael Wink

Received: 25 March 2021

Accepted: 26 April 2021

Published: 29 April 2021

Publisher's Note: MDPI stays neutral with regard to jurisdictional claims in published maps and institutional affiliations.

Copyright: (c) 2021 by the authors. Licensee MDPI, Basel, Switzerland. This article is an open access article distributed under the terms and conditions of the Creative Commons Attribution (CC BY) license (https:/ / creativecommons.org/licenses/by/ $4.0 /)$.

\begin{abstract}
We investigated the effect of varying storage time and storage temperature on fungal species' isolation as part of a case study of Illinois cave sediment samples. A deeper understanding of cave fungal communities may influence eco-epidemiology studies of emerging or re-emerging cave fungal pathogens. Using culture-dependent techniques, we isolated geophilic fungi from homogeneous cave sediment samples from three Illinois caves. Each sample was stored under five different temperatures ranging from $-80{ }^{\circ} \mathrm{C}$ to $22^{\circ} \mathrm{C}$. Cave sediment was periodically removed at five different time periods from $48 \mathrm{~h}$. to 1 year, serially diluted with distilled water, lawn plated onto two different media, and monitored for fungal colonies. We isolated colonies and confirmed identity through nrDNA sequence similarity. Our results suggest that storage time was more important than storage temperature for the isolation of a wide diversity of geophilic fungal taxa. Importantly, our results show that varying storage conditions will alter both the kind of taxa and abundance of those taxa, suggesting that comparative studies of fungal diversity across studies should employ similar storage conditions. Lastly, future investigations should utilize multiple genetic markers because the fungal barcode region lacked species-level resolution for many isolates within common Illinois geophilic fungal genera.
\end{abstract}

Keywords: culture-dependent method; diversity; ecology; mycology

\section{Introduction}

Understanding microbial (fungi and bacteria) community composition using culturebased isolation techniques remains foundational for fungal research requiring phenotypic and physiological information for a multitude of basic biological questions as well as biomedical and industrial applications [1]. Although next-generation sequencing allows rapid identification of microbial community composition without culture biases, there are disadvantages, such as the lack of follow-up physiological analysis of fungal species [2-4]. Consequently, culture-dependent methods are still important components of the scientific discovery process, especially for pathogenic fungi.

Current culture-dependent isolation techniques use a range of media that support the growth of a wide range of fungi. In addition, there are many selective media that can be utilized to isolate particular groups of fungi, including clinically important fungi [5], soil and litter fungi [6], and salt-water fungi [7]. Inhibitory compounds can be added to suppress the growth of fast-growing fungi [6] or bacteria [8]. One alternative to changing the culture medium or using inhibitory compounds is to vary the incubation temperature. This approach underscores that fungal growth and spore germination temperature requirements vary between individual fungal species. Thermophilic fungi have a growth optimum 
of $40-50{ }^{\circ} \mathrm{C}$, mesophilic fungi have a growth optimum of $20-35^{\circ} \mathrm{C}$, while psychrophilic fungi grow optimally at less than $20^{\circ} \mathrm{C}$ [9]. Similarly, some fungal spores require heat or cold treatment to activate germination [10].

In addition to varying temperature, sample storage time should be advantageous in selecting different groups of fungi. It is known that fungal spores/species have different survival rates upon exposure to freezing stress [11]. Therefore, substrate samples exposed to different durations of suboptimal temperatures should select those species with the highest stress tolerance. Similarly, storing substrate samples at temperatures that permit fungi to be metabolically active for longer periods of time have the potential to select for fungi that are slow growing [12]. Consequently, altering both sample storage time and storage temperature may better represent the fungal community in a substrate sample and more importantly provide additional isolates per sample. Increasing the diversity of fungi that can be reliably isolated is crucial to addressing environmental spread of pathogenic fungi that threaten biodiversity and human health and well-being.

Pathogenic fungi infect plants and animals, causing disease and mortality [13]. An estimated 2.2 to 3.8 million fungal species have been identified, from which only 625 have been reported to infect vertebrates [14,15]. Fungal species that affect animals can be classified either as opportunistic or pathogenic. Mycotic infections caused by opportunistic fungi-those that do not need an animal host as part of their life cycle to survive-are non-transmissible from the infected host to the environment or other hosts [15]. On the other hand, pathogenic fungi invade the host, causing a systemic or superficial infection that can then be transmitted to other hosts (direct transmission) or the environment where they can infect subsequent hosts (indirect transmission) [15].

Early detection and identification of clinically important fungal pathogens are crucial for managing emerging and re-emerging infectious diseases. For example, Pseudogymnoascus destructans, the etiologic agent of bat white-nose syndrome, has caused ongoing mass mortalities for bats in North America and is considered the worst mass mortality of any mammalian species [16] since more than six million bats have been killed, and $90 \%$ of populations in some areas have disappeared [17]. This case illustrates the essential need to identify and catalog potential threats for different animal populations from environmental samples. Thus, control and preventive strategies can be developed, and improved responses can be implemented. Although there is much information on geophilic fungi found in caves around the world $[18,19]$, there is little information on geophilic fungi from caves in the Midwest US, and, to our knowledge, there is no data about geophilic fungi in Illinois' caves.

Many studies have described methods for microfungi identification in soil [20] and leaf litter [21], as well as the effect of storage environment [22], temperature, and moisture $[23,24]$. However, to the best of our knowledge, no study has evaluated the effects of storage time and storage temperature on maximizing fungal isolate diversity from cave sediment samples in general and Illinois' caves in particular. Cave sediment samples were utilized because cave sediment samples have been shown to contain a broad range of psychrophilic, psychro-tolerant, mesophilic, and dermatophytic species [19]. The objectives of this study were to (1) describe genera and species of geophilic fungi occurring in Illinois' caves, (2) catalog pathogenic and non-pathogenic fungal communities present in cave sediment in Illinois, and (3) determine the effects of sample storage time and storage temperature on fungal isolate diversity from cave sediment samples.

To determine the effects of storage time and storage temperature on maximizing fungal isolate diversity from cave sediment samples, we subjected samples to five different temperatures over the course of one year. We hypothesized that the fungal community would be affected by both the length of time and degree of temperature at which each sample was stored. We predicted that longer storage times at more extreme temperatures would change the fungal community composition obtained through culture-dependent methods. 


\section{Materials and Methods}

\subsection{Study Area}

Three caves, representing areas in the north, central, and south of Illinois, were selected for this study (Figure 1). Upland forest, floodplain forest, and savanna communities, as well as dolomite prairies and dolomite cliffs, surround the cave in the north region of Illinois. This site is an abandoned limestone mine with several entrances, with several pools of water typically present (A); while in central Illinois (B), pine plantation and successional fields, as well as dry-mesic upland forest and floodplain forest surrounds the cave. This site has seven entrances, composed of limestone bedrock with a main stream. The south region cave (C) comprises several miles of underground streams, containing nearly pristine subterranean wilderness. This site is composed of limestone bedrock and is considered a solution cave. It harbors multiple bat species, including federal and state endangered species and invertebrate cave fauna. Many threatened and endangered species live in or around the cave systems. Birds, mammals, and herptiles live in these areas, in addition to crustaceans and insects that are endemic to these sites [25]. The caves are part of nature preserve areas, are closed to the public, and the names have been withheld to protect these unique and fragile ecosystems.

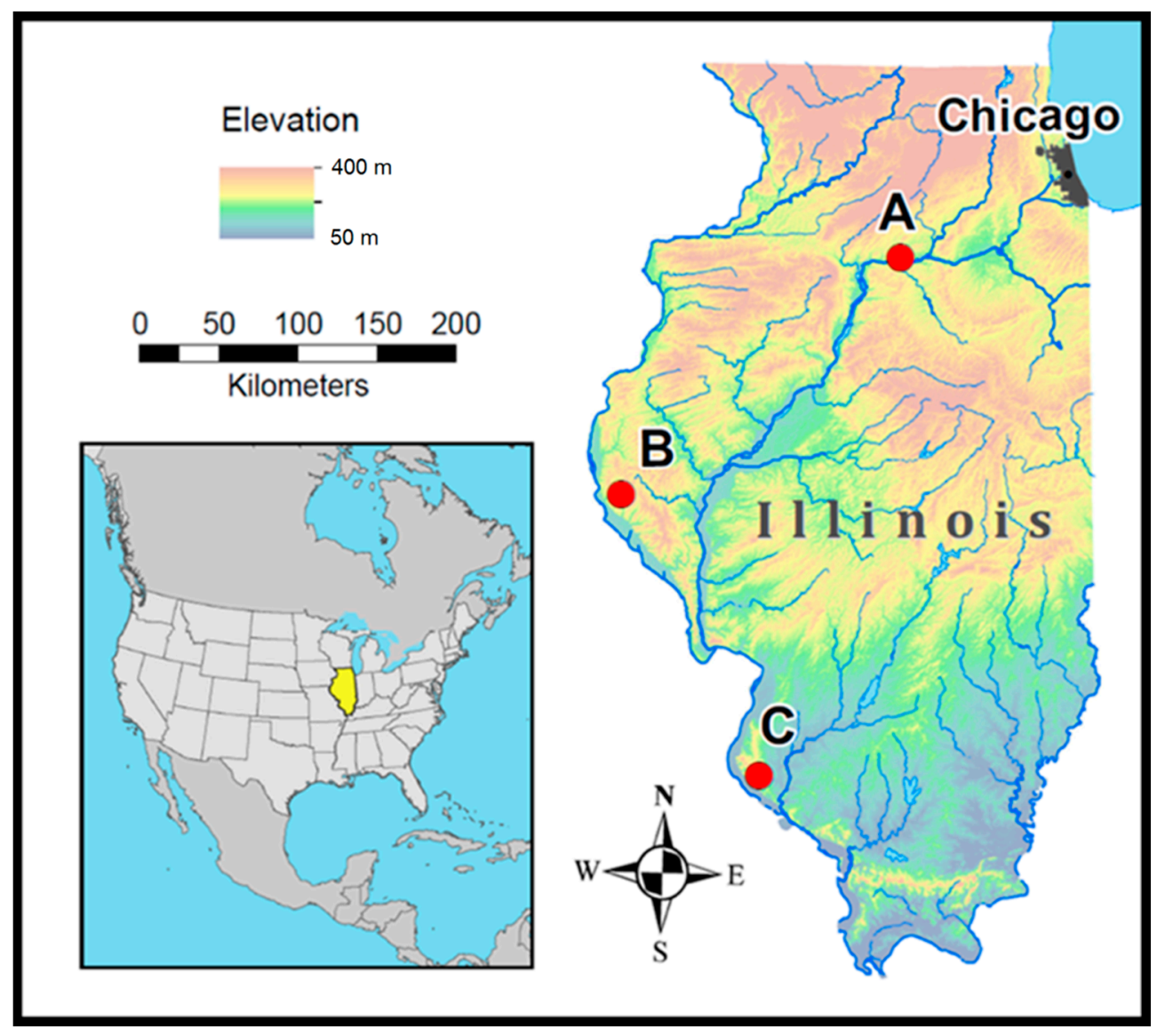

Figure 1. Location of sampling sites in Illinois. Red dots indicate sampling locations. Map generated using ESRI ArcMap 10.6.

\subsection{Collection and Isolation}

Cave sediment samples were collected in January and February 2013 from three Illinois caves that ranged in temperature from $7-12{ }^{\circ} \mathrm{C}$. Cave sediment samples consisted of sediment collected from several locations within each cave, placed in a cooler, and transported to the lab within $48 \mathrm{~h}$. Each cave sample was thoroughly mixed to make a representative homogeneous sample for each cave, divided equally into five sterile $50 \mathrm{~mL}$ tubes, and stored 
under five different temperatures $\left(22^{\circ} \mathrm{C}, 14{ }^{\circ} \mathrm{C}, 7^{\circ} \mathrm{C},-20^{\circ} \mathrm{C}\right.$, and $\left.-80{ }^{\circ} \mathrm{C}\right)$. One gram of substrate was periodically removed ( $48 \mathrm{~h}, 1$ week, 1 month, 6 months, and 1 year) from each of the $50 \mathrm{~mL}$ tubes, serially diluted $(9 \mathrm{~mL}, 90 \mathrm{~mL}, 900 \mathrm{~mL})$ with distilled water, and $400 \mu \mathrm{L}$ of each serial dilution was used to inoculate each media plate: A $400 \mu \mathrm{L}$ aliquot of each serial dilution was lawn plated onto $90 \mathrm{~mm}$ Petri plates containing potato dextrose agar (Difco) and $90 \mathrm{~mm}$ Petri plates containing Sabouraud dextrose agar (Difco) for a total of 12 plates (two per serial dilution per media for each cave/temperature/time [26,27]. Both media were amended with penicillin G (75 ppm/liter) and streptomycin sulfate (150 ppm/liter) to prevent bacterial growth. Plates were sealed with Parafilm and incubated in the dark at $7{ }^{\circ} \mathrm{C}$. Each plate was visually inspected twice a week for three weeks, followed by a final evaluation at three months. At each inspection, colonies with unique morphology per plate were transferred to individual $60 \mathrm{~mm}$ Petri plates containing the same initial isolation medium (pure culture). Petri plates were sealed with Parafilm and stored in the dark at 7 ${ }^{\circ} \mathrm{C}$. The total number of colonies per time and temperature was $n=30$.

\subsection{Culture Identification and Molecular Methods}

All isolated fungal cultures were identified through nrDNA sequence (ITS1, $5.8 \mathrm{~s}$, ITS2) similarity within the NCBI database using BLASTn. Fungal DNA was extracted using a modified $\mathrm{NaOH}$ DNA extraction method $[27,28]$. In short, actively growing fungal mycelia from two-week-old pure culture plates were added to a $1.5 \mathrm{~mL}$ centrifuge tube (up to the $0.25 \mathrm{~mL}$ line) and placed in $-80^{\circ} \mathrm{C}$ overnight. Next, $200 \mu \mathrm{L} 0.5 \mathrm{M} \mathrm{NaOH}$ solution was added to the $1.5 \mathrm{~mL}$ tube, the frozen mycelium was ground within the tube using a sterile pestle, placed on ice for 15 to 20 minutes, centrifuged at 14,000 RPM for 2 min, and $5 \mu \mathrm{L}$ of the resulting supernatant was added to $495 \mu \mathrm{L} 100 \mathrm{mM}$ Tris- $\mathrm{HCl}$ solution buffered with $\mathrm{NaOH}$ to $\mathrm{pH} 8.7-9.1$.

PCR was completed on a Bio-Rad PTC 200 thermal cycler. The total reaction volume was $25 \mu \mathrm{l}\left(12.5 \mu \mathrm{l} \mathrm{GoTaq}{ }^{\circledR}\right.$ Green Master Mix, $1 \mu \mathrm{L}$ of each $10 \mu \mathrm{M}$ primer ITS1F and ITS4, $3 \mu \mathrm{l}$ of DNA template solution and $7.5 \mu \mathrm{L}$ DNA free water). The following thermal cycle parameters were used: initial denaturation at $94{ }^{\circ} \mathrm{C}$ for $2 \mathrm{~min}$, followed by 30 cycles of $94{ }^{\circ} \mathrm{C}$ for 30 seconds, $55{ }^{\circ} \mathrm{C}$ for 45 seconds, $72{ }^{\circ} \mathrm{C}$ for 1 minute with a final extension step of $72{ }^{\circ} \mathrm{C}$ for 10 minutes. Gel electrophoresis (1\% TBE agarose gel stained with ethidium bromide) was used to verify the presence of a PCR product before purification using a Wizard ${ }^{\circledR} \mathrm{SV}$ Gel and PCR Clean-Up System (Promega, Madison, WI, USA). A BigDye ${ }^{\circledR}$ Terminator 3.1 cycle sequencing kit (Applied Biosystems Inc., Vilnius, Vilnius Region, Lithuania) was used to sequence the ITS in one direction using the ITS5 primer on an Applied Biosystems 3730XL high-throughput capillary sequencer. Sequence data were manually reviewed and edited using Sequencher 5.1 followed by isolate identification based on the top 10 sequence matches within the NCBI database using BLASTn. Closely related isolates were grouped due to recent taxonomic changes to provide a more appropriate determination at the genus level. Species-level identities were applied to isolates when all top 10 sequence matches were identical.

\subsection{Analysis}

The number of isolates per cave, temperature, and time were visualized for trends using the pheatmap function in R statistical package [29]. A linear mixed model was used to analyze the main effects, interactions, and block effects of time and temperature on the number of isolates. After initial analysis, storage time was grouped into two categories ( $\leq 1$ month $(0-1 \mathrm{M})$ and $\geq 6$ months $(6 \mathrm{M}-1 \mathrm{Y})$ since an initial mixed model analysis (nlme package in R) performed in RStudio indicated that the main effects of storage time and storage temperature across all individual sampling times was not significant which we attributed to the limited number of isolates per time/temperature. A two-tailed unpaired t-test was conducted for each potential animal pathogenic genus to determine if isolation frequency was altered due to storage time. 


\section{Results}

A total of 422 isolates from 26 fungal families (Table 1) of 52 unique taxa (Table 2) were isolated during this experiment. Apiotrichum/Trichosporon group, Mortierella, Penicillium, Pseudogymnoascus / Geomyces group were the most frequently isolated genera/group. Identified genera/group isolated over the entire storage time and storage temperatures were Apiotrichum/Trichosporoni group, Cladosporium, Debaryomyces, Epicoccum, Mortierella, Myriodontium, Oidiodendron, Penicillium, and Pseudogymnoascus/Geomyces group (Table 1).

Table 1. Isolated genera from cave sediment samples over the course of one year per storage time and storage temperature.

\begin{tabular}{|c|c|c|c|c|c|c|c|}
\hline \multirow[t]{2}{*}{ Phylum } & \multirow[t]{2}{*}{ Order } & \multirow[t]{2}{*}{ Family } & \multirow[t]{2}{*}{ Genus/Group } & \multicolumn{2}{|c|}{$\begin{array}{l}\text { Number of Total } \\
\text { Isolates Per } \\
\text { Temperature }\left({ }^{\circ} \mathrm{C}\right)\end{array}$} & \multicolumn{2}{|c|}{$\begin{array}{l}\text { Isolates per } \\
\text { Time Frame }\end{array}$} \\
\hline & & & & $\begin{array}{l}-20 \text { to } \\
-80\end{array}$ & 7 to 22 & 0 to $1 \mathrm{M}$ & $6 \mathrm{M}$ to $1 \mathrm{Y}$ \\
\hline \multicolumn{8}{|l|}{ Ascomycota } \\
\hline \multirow[t]{6}{*}{ Dothideomycetes } & Capnodiales & Cladosporiaceae & Cladosporium & 10 & 3 & 8 & 5 \\
\hline & Dothideales & Saccotheciaceae & Aureobasidium & 1 & - & 1 & - \\
\hline & Pleosporales & Didymellaceae & Epicoccum & 2 & 1 & 2 & 1 \\
\hline & & Pleosporaceae & Alternaria & 2 & 1 & - & 3 \\
\hline & Incertae sedis & Phyllostictaceae & Phyllosticta & 1 & - & - & 1 \\
\hline & $*$ & $*$ & Unidentified & - & 1 & - & 1 \\
\hline \multirow[t]{5}{*}{ Eurotiomycetes } & Eurotiales & Aspergillaceae & Penicillium & 51 & 83 & 98 & 36 \\
\hline & & & Aspergillus & 3 & 2 & 5 & - \\
\hline & Onygenales & Arthrodermataceae & $\begin{array}{l}\text { Arthroderma / } \\
\text { Chrysosporium }\end{array}$ & - & 7 & 3 & 4 \\
\hline & & * & Unidentified & 2 & 1 & 2 & 1 \\
\hline & * & * & Unidentified & 1 & 1 & 2 & - \\
\hline \multirow{5}{*}{$\begin{array}{l}\text { Incertae sedis } \\
\text { Leotiomycetes }\end{array}$} & Incertae sedis & Incertae sedis & Myriodontium & 1 & 6 & 5 & 2 \\
\hline & Helotiales & $*$ & Unidentified & 1 & 1 & 1 & 1 \\
\hline & & Myxotrichaceae & Oidiodendron & 1 & 3 & 1 & 3 \\
\hline & Thelebolales & Pseudeurotiaceae & $\begin{array}{c}\text { Pseudogymnoascus / } \\
\text { Geomyces }\end{array}$ & 27 & 44 & 29 & 42 \\
\hline & & & Pseudeurotium & - & 1 & 1 & - \\
\hline \multirow[t]{4}{*}{ Saccharomycetes } & Saccharomycetales & $\begin{array}{l}\text { Wickerhamomy- } \\
\text { cetaceae }\end{array}$ & Barnettozyma & 3 & - & 1 & 2 \\
\hline & & Saccharomycetaceae & Debaryomyces & 4 & 2 & 1 & 5 \\
\hline & & Dipodascaceae & Geotrichum & - & 1 & 1 & - \\
\hline & & & Galactomyces & - & 3 & 3 & - \\
\hline \multirow[t]{9}{*}{ Sordariomycetes } & Amphisphaeriales & Pestalotiopsidaceae & Pestalotiopsis & - & 2 & - & 2 \\
\hline & Hypocreales & Cordycipitaceae & $\begin{array}{l}\text { Simplicillium / } \\
\text { Lecanicillium }\end{array}$ & 1 & - & - & 1 \\
\hline & & Nectriaceae & Fusarium & 3 & 1 & 4 & - \\
\hline & & Incertae sedis & Ilyonectria & - & 1 & 1 & - \\
\hline & Glomerellales & Plectosphaerellaceae & Gibellulopsis & 1 & - & - & 1 \\
\hline & Sordariales & Chaetomiaceae & Unidentified & 1 & 2 & - & 3 \\
\hline & & & Chaetomium & 1 & 5 & - & 6 \\
\hline & Xylariales & Diatrypaceae & Diatrype & 2 & - & - & 2 \\
\hline & $*$ & $*$ & Unidentified & 2 & 2 & 4 & - \\
\hline * & * & * & Unidentified & 4 & 11 & 11 & 4 \\
\hline \multicolumn{8}{|l|}{ Basidiomycota } \\
\hline \multirow[t]{2}{*}{ Agaricomycetes } & Agaricales & Incertae sedis & Cyathus & - & 2 & 2 & - \\
\hline & & Psathyrellaceae & Coprinellus & 3 & 5 & - & 8 \\
\hline \multirow[t]{2}{*}{ Tremellomycetes } & Cystofilobasidiales & Mrakiaceae & Tausonia & - & 2 & - & 2 \\
\hline & Trichosporonales & Trichosporonaceae & Apiotrichum/Trichosporon & 8 & 13 & 15 & 6 \\
\hline * & $*$ & F & Unidentified & 1 & 2 & - & 3 \\
\hline \multicolumn{8}{|l|}{ Kickxellomycota } \\
\hline Kickxellomycetes & Kickxellales & Kickxellaceae & Coemansia & - & 1 & 1 & - \\
\hline \multicolumn{8}{|l|}{ Mortierellomycota } \\
\hline Mortierellomycetes & Mortierellales & Mortierellaceae & Mortierella & 24 & 35 & 35 & 24 \\
\hline
\end{tabular}


Table 1. Cont.

\begin{tabular}{|c|c|c|c|c|c|c|c|}
\hline \multirow[t]{2}{*}{ Phylum } & \multirow[t]{2}{*}{ Order } & \multirow[t]{2}{*}{ Family } & \multirow[t]{2}{*}{ Genus/Group } & \multicolumn{2}{|c|}{$\begin{array}{c}\text { Number of Total } \\
\text { Isolates Per } \\
\text { Temperature }\left({ }^{\circ} \mathrm{C}\right)\end{array}$} & \multicolumn{2}{|c|}{$\begin{array}{l}\text { Isolates per } \\
\text { Time Frame }\end{array}$} \\
\hline & & & & $\begin{array}{l}-20 \text { to } \\
-80\end{array}$ & 7 to 22 & 0 to $1 \mathrm{M}$ & $6 \mathrm{M}$ to $1 \mathrm{Y}$ \\
\hline \multicolumn{8}{|l|}{ Mucoromycota } \\
\hline \multirow{3}{*}{ Mucoromycetes } & Mucorales & Mucoraceae & Helicostylum & 1 & 2 & 3 & - \\
\hline & & & Mucor & 4 & 5 & 9 & - \\
\hline & & Rhizopodaceae & Rhizopus & - & 2 & - & 2 \\
\hline \multicolumn{8}{|l|}{ zygomycotan fungi ${ }^{1}$} \\
\hline$*$ & * & * & Unidentified & - & 2 & 2 & - \\
\hline
\end{tabular}

${ }^{1}$ Unidentified isolates that conform to the previous zygomycotan fungal group. * Unknown placement within the Phylum, Order, or Family.

- Not isolated within that specific temperature or time frame.

Table 2. Presumptive species list for isolates which could be identified to a single genus.

\begin{tabular}{|c|c|c|c|}
\hline Phylum & Class & Order & Species Epithet \\
\hline \multirow[t]{31}{*}{ Ascomycota } & Dothideomycetes & Capnodiales & $\begin{array}{c}\text { Cladosporium cladosporioides } \\
\text { Cladosporium sp. }\end{array}$ \\
\hline & & Dothideales & Aureobasidium pullulans \\
\hline & & Incertae sedis & Phyllosticta citricarpa \\
\hline & & Pleosporales & Alternaria alternata \\
\hline & & & Alternaria sp. \\
\hline & & & Epicoccum sp. \\
\hline & & & Epicoccum tobaicum \\
\hline & Eurotiomycetes & Eurotiales & Aspergillus sp. \\
\hline & & & Penicillium atramentosum \\
\hline & & & Penicillium bialowiezense \\
\hline & & & Penicillium commune \\
\hline & & & Penicillium crustosum \\
\hline & & & Penicillium expansum \\
\hline & & & Penicillium glandicola \\
\hline & & & Penicillium sp. \\
\hline & & & Penicillium vulpinum \\
\hline & Incertae sedis & Incertae sedis & Myriodontium keratinophilum \\
\hline & Leotiomycetes & Helotiales & Oidiodendron sp. \\
\hline & & Thelebolales & Pseudeurotium sp. \\
\hline & & & Pseudogymnoascus pannorum \\
\hline & & & Pseudogymnoascus sp. \\
\hline & Saccharomycetes & Saccharomycetales & Barnettozyma californica \\
\hline & & & Debaryomyces hansenii \\
\hline & & & Galactomyces sp. \\
\hline & & & Geotrichum candidum \\
\hline & Sordariomycetes & Amphisphaeriales & Pestalotiopsis sp. \\
\hline & & Glomerellales & Gibellulopsis nigrescens \\
\hline & & Hypocreales & $\begin{array}{l}\text { Fusarium sp. } \\
\text { Iluonectria robusta }\end{array}$ \\
\hline & & Sordariales & Chaetomium crispatum \\
\hline & & & Chaetomium sp. \\
\hline & & Xylariales & Diatrype stigma \\
\hline \multirow[t]{5}{*}{ Basidiomycota } & Agaricomycetes & Agaricales & Coprinellus micaceus \\
\hline & & & Cyathus ibericus \\
\hline & Tremellomycetes & Cystofilobasidiales & Tausonia pullulans \\
\hline & & Trichosporonales & Apiotrichum dulcitum \\
\hline & & & Arthroderma quadrifidum \\
\hline
\end{tabular}


Table 2. Cont.

\begin{tabular}{|c|c|c|c|}
\hline Phylum & Class & Order & Species Epithet \\
\hline Kickxellomycota & Kickxellomycetes & Kickxellales & Coemansia sp. \\
\hline Mortierellomycota & Mortierellomycetes & Mortierellales & $\begin{array}{c}\text { Mortierella alpina } \\
\text { Mortierella elongata } \\
\text { Mortierella hyalina } \\
\text { Mortierella polycephala } \\
\text { Mortierella sp. }\end{array}$ \\
\hline Mucoromycota & Mucoromycetes & Mucorales & $\begin{array}{c}\text { Helicostylum pulchrum } \\
\text { Helicostylum sp. } \\
\text { Mucor aligarensis } \\
\text { Mucor flavus } \\
\text { Mucor nidicola } \\
\text { Mucor racemosus } \\
\text { Mucor sp. } \\
\text { Rhizopus oryzae }\end{array}$ \\
\hline
\end{tabular}

Sampling sites were statistically different from each other $(p<0.01)$, time frames were statistically significant $(0-1$ month vs. 6 months -1 year; $p=0.03)$, but the effect of temperature was not statistically significant $(p=0.8)$ when the isolated community was analyzed at the genus level. The south cave contained a greater number of the Pseudogymnoascus/Geomyces group and Mortierella isolates as compared to the central and north locations. The genus Aspergillus had a significant reduction in isolation frequency after the substrate was stored beyond six months $(p=0.04)$.

Alternaria, Apiotrichum/Trichosporon group, Aspergillus, Chaetomium, Cladosporium, Coprinellus, Debaryomyces, Epicoccum, Fusarium, Helicostylum, Myriodontium, Mortierella, Mucor, Oidiodendron, Penicillium, and Pseudogymnoascus/Geomyces group were isolated at both storage temperature ranges $\left(-80{ }^{\circ} \mathrm{C}\right.$ to $-20{ }^{\circ} \mathrm{C}$ and $7{ }^{\circ} \mathrm{C}$ to $\left.22{ }^{\circ} \mathrm{C}\right)$ (Table 1). Arthroderma/Chrysosporium group, Apiotrichum/Trichosporon group, Cladosporium, Debaryomyces, Epicoccum, Mortierella, Myriodontium, Oidiodendron, Penicillium, and Pseudogymnoascus/Geomyces group were isolated at both storage time frames.

In this study, seven different fungal genera with species that could affect animals were isolated from Illinois caves. These isolates come from three fungal phylum, Ascomycota, Basidiomycota, and Mucoromycota, and occur in the following: Arthroderma/Chrysosporium group, Apiotrichum/Trichosporon group, Aspergillus, Pseudogymnoascus/Geomyces group, Mortierella, Myriodontium, and Mucor. The Pseudogymnoascus/Geomyces group was isolated more frequently at one year of storage (Figure 2A). In contrast, Apiotrichum/Trichosporon group and Myriodontium were isolated more frequently at one month of storage (Figure 2B). 


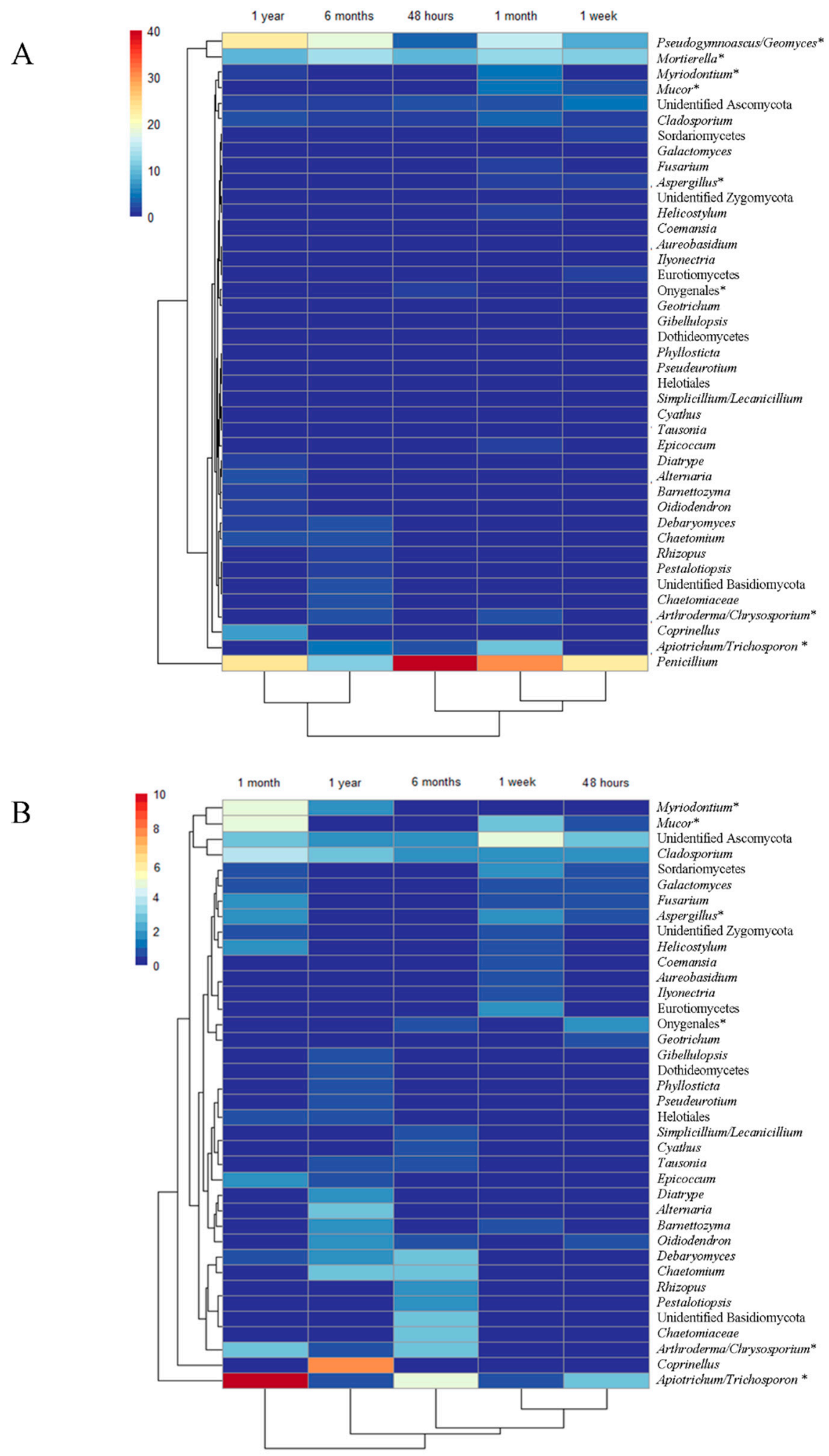

Figure 2. Pheatmap displaying fungal isolation patterns over storage time frame. (A) All Fungal taxa isolated; (B) Taxa isolated in low frequency. Panel (A) indicated 0-1 month were more similar to each other than 6 month-1 year based on storage time; Panel (B) demonstrates that low-frequency isolates were isolated more frequently at different time frames throughout the experiment. Potential fungal taxa indicated with an*. 


\section{Discussion}

The results of this study support our hypothesis that altering both the sample storage time and storage temperature effectively increased the overall diversity of cave fungal genera isolated from cave sediment samples (Table 1); however, only storage time was statistically significant for the overall community. Storage temperature was not statistically significant for the overall community; however, psychrophilic fungi, like Pseudogymnoascus destructans which grows at temperatures less than $20^{\circ} \mathrm{C}$ [30], would not be isolated at temperatures above their growth range suggesting incubation temperature could limit some species. Another important finding of our study is that characterizing Illinois cave geophilic fungal diversity is difficult because the fungal barcode (ITS1, 5.8, ITS2) region lacks species-level resolution for many isolates within common cave geophilic genera. Therefore, the use of multiple genetic markers will benefit future investigations.

Our results support previous research on soil bacteria [31] and forest soil fungi [32,33], suggesting that varying soil storage time and the temperature is a robust method to increase isolate diversity from most sediment samples. In addition, our study demonstrates that culture-based cave diversity metrics can be altered by logistical constraints if samples are collected and stored for long periods of time. The consistent shifts in isolates cultured at different storage times and temperatures may be driven by community (competition) and physiological (freeze tolerance, optimal growth conditions, and spore germination) traits.

The majority of the 422 isolates belong in the phylum Ascomycota, with a smaller number in Basidiomycota, Kickxellomycota, Mortierellomycota, and Mucoromycota (Table 1). These are the most abundant taxa commonly reported from cave studies worldwide [18,19]. From the 28 families identified in our study, 11 are among the most frequently reported from caves and mines, with genera in the families Mucoraceae and Nectriaceae at the top of the list of the 20 most reported around the world [19]. Furthermore, 10 genera identified in this study are frequently found in solution caves which are the most commonly occurring type of caves, formed by slowly moving water that dissolves rocks along and adjacent to joints/fractures, faults, and layers in the rock [18]. We did not evaluate the fungal communities in bats or other animals that use caves and mines as hibernacula. However, a previous study focused on evaluating psychrophilic fungi of healthy hibernating bats in Illinois collected before the arrival of WNS in the U.S. (WNS free bats) identified Penicillium, Mortierella, Cladosporium, Trichosporon, Fusarium, and Geomyces [34]. These six genera isolated from the wings of Illinois bats are consistent with previously documented fungal taxa reported in hibernating bats worldwide [34-37] and have been documented by culture-based surveys from hibernacula sediments in the eastern U.S. [38] and by culture identification and molecular methods in our study. Some of the genera isolated from bats [34] and sediment samples in Illinois could be pathogenic to animals. Johnson et al. [34] described some minor damage to the bats' wings studied [34]. Future studies evaluating the potential of sediment-borne pathogens identified in these caves and the role of common sources for potential disease outbreaks build the eco-epidemiology knowledge of mycotic pathogens that may become associated with different caves and mines in Illinois. With this knowledge, we can implement pathogen and disease surveillance programs in vertebrates in a timely manner to inform prevention and control strategies [39].

Aureobasidium, Barnettozyma, Diatrype, Gibellulopsis, and Simplicillium/Lecanicillium groups were solely isolated at storage temperatures below $0{ }^{\circ} \mathrm{C}$, suggesting that these isolates may be psychrophilic, have low population densities, or are slow growing and require the reduction of faster growing species to facilitate being sampled. These taxa may also have physiological adaptations to tolerate freezing, such as producing anti-freeze compounds [40], allowing them to preferentially survive the extreme storage temperatures. In contrast, the Arthroderma /Chrysosporium group's isolation only occurred at temperatures above $0{ }^{\circ} \mathrm{C}$, suggesting that these isolates may be associated with mammals or require higher temperatures for optimal growth as compared to geophilic cave dermatophytes [41]. Similarly, research has demonstrated that caves harbor many species in the Pseudogymnoascus / Geomyces group [6,42] that are psychrotolerant bat-associated cave species [37], 
while other Pseudogymnoascus and Geomyces species are reported to be psychrophilic and have adaptations that facilitate survival and reproduction in cave environments with low nutrients [42]. Our results showed that many isolates in the Pseudogymnoascus / Geomyces group were obtained over the entire sample storage temperature range $\left(-80^{\circ} \mathrm{C}\right.$ to $\left.22^{\circ} \mathrm{C}\right)$ and that a wider range of storage temperatures may be needed to effectively isolate both psychrophilic and psychrotolerant species within this genus.

Similar to storage temperature, sample storage time was important as many genera were solely isolated from the soil samples stored $\leq 1$ month or stored $\geq 6$ months (Table 1 ). Common, widespread genera that produce abundant asexual spores (Penicillium and Trichosporon) had a reduction in isolation frequency at $\geq 6$ months. Research has shown that storing samples above freezing temperatures may reduce spore viability in some fungal species if spores are imbibed but conditions remain unfavorable for spore germination [10]. Our results do not indicate that prolonged storage time eliminated all prolific spore-forming genera but rather suggest a reduction in the isolation frequency of sensitive species that would lead to biases when interpreting dominate fungal taxa within caves.

Another reported reason why storing soil samples above $0^{\circ} \mathrm{C}$ for a prolonged duration would benefit obtaining additional species is that fungi are still metabolically active at these temperatures [33]. Active, fast-growing fungi are likely to deplete sediment carbon resources resulting in an increased proportion of slower-growing oligotrophic fungi over time. Inversely, storing samples in a way that permits fungi to be metabolically active could initially favor fast spore producers by allowing them to reproduce and preferentially increase their spore load. Consequently, culturing fungi from sediment samples under different conditions should decrease culturing biases by increasing opportunities to isolate fungal species that thrive under different sets of conditions.

\section{Conclusions}

We have demonstrated that altering cave sediment storage temperature and storage time can increase the diversity of isolated fungi from cave sediment samples. Possible reasons for these results are differences in freeze tolerance between species, differences in growth requirements, and differences in competitive abilities between species. Further research and a larger study are needed to determine the exact underlying mechanisms, but our results demonstrate that sample storage can significantly affect the culturable fungal community. Comparing studies with different storage conditions should be evaluated with caution since this introduces biases for the taxa isolated and abundance of dominant taxa. Overall, the use of varying storage temperature and time appears to provide an effective method for obtaining a greater number of fungal species within a given sample.

Author Contributions: Conceptualization, N.E.M.-P. and A.N.M.; formal analysis, D.B.R. and E.B.; investigation, D.B.R., G.C.A., N.E.M.-P. and A.N.M.; funding acquisition, N.E.M.-P. and A.N.M.; writing-original draft preparation, D.B.R., N.A.R., G.C.A., E.B., A.N.M. and N.E.M.-P.; writingreview and editing, D.B.R., N.A.R., G.C.A., E.B., A.N.M. and N.E.M.-P. All authors have read and agreed to the published version of the manuscript.

Funding: This study was supported by the University of Illinois at Urbana-Champaign ACES James Scholar Program, the Fish and Wildlife Service Federal Aid in Wildlife Restoration Project (W-146R), the Illinois Department of Natural Resources State Wildlife Grants Program (Project Number T-78-R-1), and the Section 6 Endangered and Threatened Species Program (Project Number E-54-R-1).

Institutional Review Board Statement: Not applicable.

Informed Consent Statement: Not applicable.

Data Availability Statement: The data presented in this study are available on request from the corresponding authors.

Acknowledgments: The authors wish to thank the Natural Resource Managers that protect the natural areas of the State of Illinois, Ed Heske, Joe Kath, Joe Merritt, and Steve Taylor for collecting the soil samples used in this study and William M Brown for assistance with the mapping efforts. 
Conflicts of Interest: The authors declare no conflict of interest. The funders had no role in the design of the study; in the collection, analyses, or interpretation of data; in the writing of the manuscript, or in the decision to publish the results.

\section{References}

1. Panasenko, V.T. Ecology of Microfungi. Bot. Rev. 1967, 33, 189-215. [CrossRef]

2. Ramos, C.L.; de Almeida, E.G.; Freire, A.L.; Schwan, R.F. Diversity of bacteria and yeast in the naturally fermented cotton seed and rice beverage produced by Brazilian Amerindians. Food Microbiol. 2011, 28, 1380-1386. [CrossRef]

3. Al-Awadhi, H.; Dashti, N.; Khanafer, M.; Al-Mailem, D.; Ali, N.; Radwan, S. Bias problems in culture-independent analysis of environmental bacterial communities: A representative study on hydrocarbonoclastic bacteria. SpringerPlus 2013, 2, 369. [CrossRef]

4. Shade, A.; Hogan, C.S.; Klimowicz, A.K.; Linske, M.; McManus, P.S.; Handelsman, J. Culturing captures members of the soil rare biosphere. Environ. Microbiol. 2012, 14, 2247-2252. [CrossRef]

5. Tsao, P.H. Selective media for isolation of pathogenic fungi. Annu. Rev. Phytopathol. 1970, 8, 157-186. [CrossRef]

6. Frankland, J.C.; Dighton, J.; Boddy, L. Methods for studying fungi in soil and forest litter. In Methods in Microbiology; Grigorova, R., Norris, J.R., Eds.; Academic Press: New York, NY, USA, 1990; Volume 22, pp. 333-404.

7. Fuller, M.S.; Fowles, B.E.; McLaughlin, D.J. Isolation and pure culture study of marine phycomycetes. Mycologia 1964, 56, 745-756. [CrossRef]

8. Mueller, G.M.; Bills, G.F.; Foster, M.S. Biodiversity of Fungi: Inventory and Monitoring Methods; Elsevier Academic Press: San Diego, CA, USA, 2004; p. 612.

9. Kirk, P.M.; Cannon, P.F.; Minter, D.W.; Stalpers, J.A. Ainsworth E Bisby's Dictionary of the Fungi; CAB International: Wallingford, $\mathrm{UK}, 2008$.

10. van Etten, J.L.; Dahlberg, K.R.; Russo, G.M. Fungal spore germination. In Fungal Differentiation: A Contemporary Synthesis; Smith, J.E., Ed.; Marcel Dekker: New York, NY, USA, 1983; pp. 235-266.

11. Lehto, T.; Brosinsky, A.; Heinonen-Tanski, H.; Repo, T. Freezing tolerance of ectomycorrhizal fungi in pure culture. Mycorrhiza 2008, 18, 385-392. [CrossRef]

12. Morris, A.J.; Byrne, T.C.; Madden, J.F.; Reller, L.B. Duration of incubation of fungal cultures. J. Clin. Microbiol. 1996, $34,1583-1585$. [CrossRef]

13. Sharon, A.; Shlezinger, N. Fungi infecting plants and animals: Killers, non-killers, and cell death. PLoS Pathog. 2013, 9, e1003517. [CrossRef] [PubMed]

14. Hawksworth, D.L.; Lücking, R. Fungal diversity revisited: 2.2 to 3.8 million species. Microbiol. Spectr. 2017, 5. [CrossRef]

15. de Hoog, G.S.; Ahmed, S.A.; Danesi, P.; Guillot, J.; Gräser, Y. Distribution of pathogens and outbreak fungi in the fungal kingdom. In Emerging and Epizootic Fungal Infections in Animals; Seyedmousavi, S., de Hoog, G., Guillot, J., Verweij, P., Eds.; Springer: Cham, Switzerland, 2018; pp. 3-16.

16. Seyedmousavi, S.; Bosco, S.D.M.; De Hoog, S.; Ebel, F.; Elad, D.; Gomes, R.R.; Jacobsen, I.D.; Jensen, H.E.; Martel, A.; Mignon, B.; et al. Fungal infections in animals: A patchwork of different situations. Med. Mycol. J. 2018, 56, S165-S187. [CrossRef]

17. White-Nose Syndrome: The Devastating Disease of Hibernating Bats in North America. U.S. Fish and Wildlife Fact Sheet, Updated July 2019. Available online: https://www.whitenosesyndrome.org/mmedia-education/white-nose-syndrome-factsheet-june-2018 (accessed on 19 March 2021).

18. Man, B.; Wang, H.; Xiang, X.; Wang, R.; Yun, Y.; Gong, L. Phylogenetic diversity of culturable fungi in the Heshang Cave, central China. Front. Microbiol. 2015, 6, 1158. [CrossRef]

19. Vanderwolf, K.J.; Malloch, D.; McAlpine, D.F.; Forbes, G.J. A world review of fungi, yeasts, and slime molds in caves. Int. J. Speleol. 2013, 42, 77-92. [CrossRef]

20. Christensen, M. Soil microfungi of dry to mesic conifer-hardwood forests in northern Wisconsin. Ecology 1969, 50, 9-27. [CrossRef]

21. Paulus, B.; Gadek, P.; Hyde, K.D. Estimation of microfungal diversity in tropical rainforest leaf litter using particle filtration: The effects of leaf storage and surface treatment. Mycol. Res. 2003, 107, 748-756. [CrossRef] [PubMed]

22. Hong, T.D.; Gunn, J.; Ellis, R.H.; Jenkins, N.E.; Moore, D. The effect of storage environment on the longevity of conidia of Beauveria bassiana. Mycol. Res. 2001, 105, 597-602. [CrossRef]

23. Hong, T.D.; Ellis, R.H.; Moore, D. Development of a model to predict the effect of temperature and moisture on fungal spore longevity. Ann. Bot. 1997, 79, 121-128. [CrossRef]

24. Summerbell, R.C. Fungi associated with vertebrates. Biodivers. Fungi Invent. Monit. Methods 2004, 454-465. Available online: https: / / www.cabdirect.org/?target=\%2fcabdirect\%2fabstract\%2f20198637227 (accessed on 19 March 2021).

25. DauBach, C.; DauBach, P.; Taylor, S. Acquisition of the Paul Wightman Subterranean Nature Preserve. NSS News. 2015. Available online: https://www.inhs.illinois.edu/files/4114/4528/9003/DaubachEtAl_2015_AcquisitionofPWNSP_NSS-News_ April_v73n4p14-16.pdf (accessed on 19 March 2021).

26. Karunarathna, S.C.; Dong, Y.; Karasaki, S.; Tibpromma, S.; Hyde, K.D.; Lumyong, S.; Xu, J.; Sheng, J.; Mortimer, P.E. Discovery of novel fungal species and pathogens on bat carcasses in a cave in Yunnan Province, China. Emerg. Microbes. Infect. 2020, 9, 1554-1566. [CrossRef] 
27. Raudabaugh, D.B.; Miller, A.N. Morphogenetic effect of L-cysteine on Pseudogymnoascus destructans and related species. Mycosphere 2014, 5, 737-746. [CrossRef]

28. Osmundson, T.W.; Eyre, C.A.; Hayden, K.M.; Dhillon, J.; Garbelotto, M.M. Back to basics: An evaluation of NaOH and alternative rapid DNA extraction protocols for DNA barcoding, genotyping, and disease diagnostics from fungal and oomycete samples. Mol. Ecol. Resour. 2013, 13, 66-74. [CrossRef] [PubMed]

29. RStudio: Integrated Development for R; RStudio, Inc.: Boston, Massachusetts. 2015. Available online: http://www.rstudio.com/ (accessed on 19 March 2021).

30. Blehert, D.S.; Hicks, A.C.; Behr, M.J.; Meteyer, C.U.; Berlowski-Zier, B.M.; Buckles, E.L.; Coleman, J.T.H.; Darling, S.R.; Gargas, A.; Niver, R.; et al. Bat white-nose syndrome: An emerging fungal pathogen? Science 2009, 323, 227-227. [CrossRef]

31. Rubin, B.E.R.; Gibbons, S.M.; Kennedy, S.; Hampton-Marcell, J.; Owens, S.; Gilbert, J.A. Investigating the impact of storage conditions on microbial community composition in soil samples. PLoS ONE 2013, 8, e70460. [CrossRef]

32. Carreiro, M.M.; Koske, R.E. Room temperature isolations can bias against selection of low temperature microfungi in temperate forest soils. Mycologia 1992, 84, 886-900. [CrossRef]

33. Vieira, F.C.S.; Nahas, E. Microbial counts of dark red latosol samples stored at different temperatures. Rev. Microbiol. 1998, 29. [CrossRef]

34. Johnson, L.J.; Miller, A.N.; McCleery, R.A.; McClanahan, R.; Kath, J.A.; Lueschow, S.; Porras-Alfaroa, A. Psychrophilic and psychrotolerant fungi on bats and the presence of Geomyces spp. on bat wings prior to the arrival of white nose syndrome. Appl. Environ. Microbiol. 2013, 79, 5465-5471. [CrossRef] [PubMed]

35. Vanderwolf, K.J.; McAlpine, D.F.; Malloch, D.; Forbes, G.J. Ectomycota associated with hibernating bats in eastern Canadian caves prior to the emergence of white-nose syndrome. Northeast. Nat. 2013, 20, 115-130. [CrossRef]

36. Mok, W.Y.; Luizao, R.C.C.; Barreto da Silva, M.S. Isolation of fungi from bats of the Amazon Basin. Appl. Environ. Microbiol. 1982, 44, 570-575. [CrossRef] [PubMed]

37. Larcher, G.; Bouchara, J.P.; Pailley, P.; Montfort, D.; Beguin, H.; De Bièvre, C.; Chabasse, D. Fungal biota associated with bats in western France. J. Mycol. Med. 2003, 13, 29-34.

38. Lorch, J.M.; Lindner, D.L.; Gargas, A.; Muller, L.K.; Minnis, A.M.; Blehert, D.S. A culture-based survey of fungi in soil from bat hibernacula in the eastern United States and its implications for detection of Geomyces destructans, the causal agent of bat white-nose syndrome. Mycologia 2013, 105, 237-252. [CrossRef]

39. Shabbir, M.Z.; Jamil, T.; Ali, A.A.; Ahmad, A.; Naeem, M.; Chaudhary, M.H.; Bilal, M.; Ali, M.A.; Muhammad, K.; Yaqub, T.; et al. Prevalence and distribution of soil-borne zoonotic pathogens in Lahore district of Pakistan. Front. Microbiol. 2015, 6, 917. [CrossRef] [PubMed]

40. D'Amico, S.; Collins, T.; Marx, J.C.; Feller, G.; Gerday, C. Psychrophilic microorganisms: Challenges for life. EMBO Rep. 2006, 7, 385-389. [CrossRef] [PubMed]

41. Weitzman, I.; Summerbell, R.C. The dermatophytes. Clin. Microbiol. Rev. 1995, 8, 240-259. [CrossRef] [PubMed]

42. Hayes, M.A. The Geomyces fungi: Ecology and distribution. BioScience 2012, 62, 819-823. [CrossRef] 